\title{
Species of myxomycetes new to Sweden with additional records of some rarely collected species
}

\author{
UNO H. ELIASSON and GRAZINA ADAMONYTE
}

\begin{abstract}
ELIASSON, U. H. \& ADAMONYTE, G. 2009: Species of myxomycetes new to Sweden with additional records of some rarely collected species. - Karstenia 49:33-39. Helsinki. ISSN 0453-3402.

Eleven species of myxomycetes are formally reported from Sweden for the first time, namely Collaria lurida, Cribraria persoonii, Diderma cinereum, Fuligo leviderma, Lamproderma pseudomaculatum, Physarum crateriforme, Stemonitis pallida, Stemonitopsis amoena, S. gracilis, S. subcaespitosa and Symphytocarpus impexus. A possibly undescribed species of Macbrideola is discussed and illustrated. New records of several rarely collected species are cited, among them Hemitrichia abietina, H. leiotricha and Physarum diderma. The great variation of Physarum crateriforme in moist chamber cultures is discussed.
\end{abstract}

Key words: Swedish myxomycetes, Macbrideola, Physarum crateriforme, Stemonitopsis

Uno H. Eliasson, Department of Plant and Environmental Sciences, University of Gothenburg, Box 461, SE 40530 Gothenburg, Sweden /uno.eliasson@dpes.gu.se, uno. eliasson@bredband.net/

Grazina Adamonyte, Institute of Botany, Zaliuju ezeru 49, LT-2021 Vilnius, Lithuania / grazina.adamonyte@botanika.lt/

\section{Introduction}

A foray in the provinces of Norrbotten and Lappland in north Sweden, north of $65^{\circ} 30^{\prime} \mathrm{N}$, in August 2007 yielded four species of myxomycetes new to Sweden as well as several records of species new to this part of the country. Eleven species new to Sweden are reported in this paper based on records from various provinces. Included are also several new records of selected species collected only a few times before. A deviant collection of Macbrideola possibly representing an undescribed species is discussed and illustrated.

Two papers (Marstad 1995, Kylin 1998) with altogether six field-related new records, Badhamia nitens Berk., Badhamiopsis cavifera
Nann.-Bremek. \& Y. Yamam., Licea operculata (Wingate) G. W. Martin, Reticularia splendens Morgan, Stemonaria longa (Peck) Nann.Bremek., R. Sharma \& Y. Yamam. and Stemonitis lignicola Nann.-Bremek., were mistakenly overlooked in the most recent summary of Swedish myxomycetes (Eliasson \& Gilert 2007). This brings the total number of species now formally reported from Sweden to ca 225. Some of the records based on literature reports remain to be verified.

Although most species of myxomycetes appear to be more or less ubiquitous, developing where the ecological conditions and microhabitats are right, many species show distinct preferences for special climate zones. Few species appear to be absolutely restricted to a particular 
region or climatic zone, and most species may occasionally be found as isolated individuals outside their typical distribution area. Relevant examples relating to Sweden are the two species Hemitrichia calyculata (Speg.) M. L. Farr and $H$. serpula (Scop.) Rostaf. which are very common in tropical to warm-temperate regions but have so far been found only once and twice, respectively, in Sweden. The first species is known from the province of Västergötland (Gothenburg), the second from the provinces of Västergötland (Gothenburg) and Södermanland. Both species have conspicuous fruitbodies and should have been more frequently collected had the species been more common. The likewise predominantly tropical to warm-temperate species Physarella oblonga (Berk. \& M. A. Curtis) Morgan has been found in Sweden only under greenhouse conditions (Kylin 1998).

\section{List of species}

Species are treated in alphabetical order. The taxonomy follows that of Lado (2001). Provinces of Sweden are cited from south to north. Records resulting from moist chamber cultures have been indicated with "mc", other records are field collections. The collection date of moist chamber developments is that when the substratum was collected. Unless stated otherwise specimens are deposited in herbarium GB.

\section{Arcyria affinis Rostaf.}

Norrbotten: $25 \mathrm{~km}$ SE of Älvsbyn, Nature Reserve Lustgården, Aug 2007 Eliasson \& Adamonyte 6923.

In Sweden previously known from a single collection from Torne Lappmark in the province of Lappland (Schinner 1983).

Badhamia lilacina (Fr.) Rostaf.

Västergötland: Töllsjö, Sep 2001 Eliasson 5731, Oct 2006 Eliasson 6617. Västmanland: Ramnes, Aug 1990 Jansson s. n. Norrbotten: Vicinity of Sikfors, Aug 2007 Eliasson \& Adamonyte 6716, 6729.

The holotype is from the province of Småland in Sweden. This is the first time the species is reported from other Swedish provinces.

Collaria lurida (Lister) Nann.-Bremek. (Comatricha lurida Lister)
Representative specimens from different provinces:

Halland: Ca $20 \mathrm{~km}$ ENE of Falkenberg, mc, July 2003 Eliasson \& Gilert 6143; Särö Västerskog, Sep 2005 Eliasson 6404. Västergötland: Töllsjö, mc, Jan 2008 Eliasson 6949. Norrbotten: Sikfors, Aug 2007 Eliasson \& Adamonyte 6712.

Collected in the field and obtained in mc cultures on decaying wood of Picea and Quercus. The widely separate records indicate a widespread, probably common species although overlooked and not previously reported from Sweden.

Cribraria microcarpa (Schrad.) Pers.

Halland: Särö Västerskog, May 2003, mc, Eliasson \& Gilert 6094, Jan 2007, mc, Eliasson 6659. Västergötland: Töllsjö, Dec 2006, mc, Eliasson 6650. Norrbotten: Vicinity of Sikfors, Aug 2007 Eliasson \& Gilert 6718.

Although previously reported only from the provinces of Öland and Småland (Santesson 1964) this is almost certainly a common species over most of Sweden but easily overlooked in the field due to its small size. Most fruitbodies have been obtained in moist chamber cultures.

Cribraria persoonii Nann.-Bremek.

Norrbotten: Ca 5 km S of Sikfors, Aug 2007 Eliasson \& Adamonyte 6866.

Characteristic features of this species are dark-stalked globose sporothecae 0.5-0.8 mm diam., a sharply delimited radially wrinkled or striate peridial cup normally with narrow more or less finger-like projections along the margin, slightly thickened nodes of the peridial net and spores 6-7.5 $\mu \mathrm{m}$ in diam. Like in several members of the genus as currently accepted the variation range in several morphological characters overlaps those of other species.

This is the first record of this species from Sweden.

\section{Diderma cinereum Morgan}

Norrbotten: Ca $1 \mathrm{~km} \mathrm{~S}$ of Sikfors, ca $35 \mathrm{~km}$ WSW of Luleå, on Dicranum in moist conifer forest with forest floor covered with Sphagnum and Dicranum, Aug. 2007 Eliasson \& Adamonyte 6756; between Sikfors and Älvsbyn, Aug. 2007 Eliasson \& Adamonyte 6786.

The species has not previously been reported from Sweden. 
Didymium crustaceum Fr.

Angermanland: Anundsjö, Sep 1973 Strid 13713 (GB, S). Jämtland: Ström, Vågdalen, Sep 1972 Strid 11655. Västerbotten: Vännäs, Sep 1971 Strid 8992. Norrbotten: Sikfors, Aug 2007 Eliasson \& Adamonyte 6872.

Apart from an early citation (Fries 1849) from the province of Västergötland no records of this species have ever been published from Sweden.

Fuligo leviderma H. Neubert, Nowotny \& K. Baumann

Representative specimens from different provinces:

Bohuslän: Hisingen, Aug 1982 Eliasson 3432. Västergötland: Halleberg, Sep 1974 Hallingbäck s. n.; Härskogen Nature Reserve, Sep 1994 Eliasson 4712; Partille, Oct 2002 Niklasson s. $n$. Närke: Snavlunda, Nov 2003 Nilsson s. n.; Viby, Nov 2007 Nilsson s. n. Uppland: Ärentuna, Sep 1942 Lundell s. $n$.

An autumn or late-autumn species which is probably spread over the greater part of Sweden but which, until less than two decades ago, has been overlooked and probably generally regarded as a form of the variable Fuligo septica (L.) F. H. Wigg. Decaying wood and bark of Populus appears to be the favoured substratum.

Hemitrichia abietina (Wigand) G. Lister Norrbotten: Vicinity of Sikfors, on decaying wood, Aug 2007 Eliasson \& Adamonyte 6758.

In Sweden previously known from the provinces of Uppland and Ångermanland (Fries 1912).

Hemitrichia leiotricha (Lister) G. Lister Västergötland: Vårgårda, Mar 1968 Eliasson 2586; Alingsås, Östad Säteri, mc, Apr 2007 Eliasson \& Sjögren 6682.

A rarely collected species in Sweden, previously reported from the provinces of Uppland and Jämtland (Santesson 1964). The Swedish records show a wide range of different substrata (dead branches of Betula, withered rachises of Dryopteris, dead leaves of Elymus and Loiseleuria). Dead stems of Calluna have been cited as a common substratum for this species in Great Britain (Ing 1999).
Lamproderma pseudomaculatum Mar. Mey. \& Poulain

Dalsland: Rännelanda, on dead Populus leaves on the ground, Apr 1972 Andersson s. n. (dupl. det. M. Meyer).

A so-called snow-line myxomycete reported for the first time from Sweden.

Licea operculata (Wingate) G. W. Martin Halland: Särö Västerskog, mc, Sep 2006 Eliasson 6600. Västergötland: Alingsås, Östad, mc, April 2007 Eliasson \& Sjögren 6677. Lappland: Lycksele, Tannfors, mc, April 2005 Eliasson \& Forsberg 6325.

Obtained in mc cultures on mosses and on leaf and herb litter.

This species was first mentioned from Sweden by Marstad (1995) without providing locality. It is probably a common species but overlooked due to its small size.

Macbrideola sp. - Figs. 1-6

Västergötland: Alingsås, Nolhaga, mc culture on bark from living Acer platanoides, Aug 2006 Eliasson 6578.

Sporothecae globose, $0.20-0.25 \mathrm{~mm}$ in diameter (Fig. 5). Stalk mostly robust, shorter to somewhat longer than the sporotheca diameter, translucent at the base, ending in a rounded somewhat swollen columella (Fig. 1). Capillitial threads ca $3.5 \mu \mathrm{m}$ wide at the base, dichotomously branched, mostly blunt at the apex (Fig. 3) or ending in an up to $5 \mu \mathrm{m}$ long pointed tip. Spores (Figs. 2, 3) ca $9.5 \mu \mathrm{m}$, pale by transmitted light, faintly warted and with darker patches formed by aggregation of warts.

A few sporocarps developed on the substratum in close association with sporocarps of Macbrideola cornea (G. Lister \& Cran) Alexop. (Fig. 6). Although the variation in stalk length and diameter of sporotheca is considerable, the sporotheca is conspicuously larger than that of M. cornea and the stalk is shorter and wider. The rounded swollen columella is very different from that of the latter species. No differences in spore structure can be seen under the light microscope and the possibility of a monstrous development of $M$. cornea has been considered. Further investigations will await the results of additional cultures. 

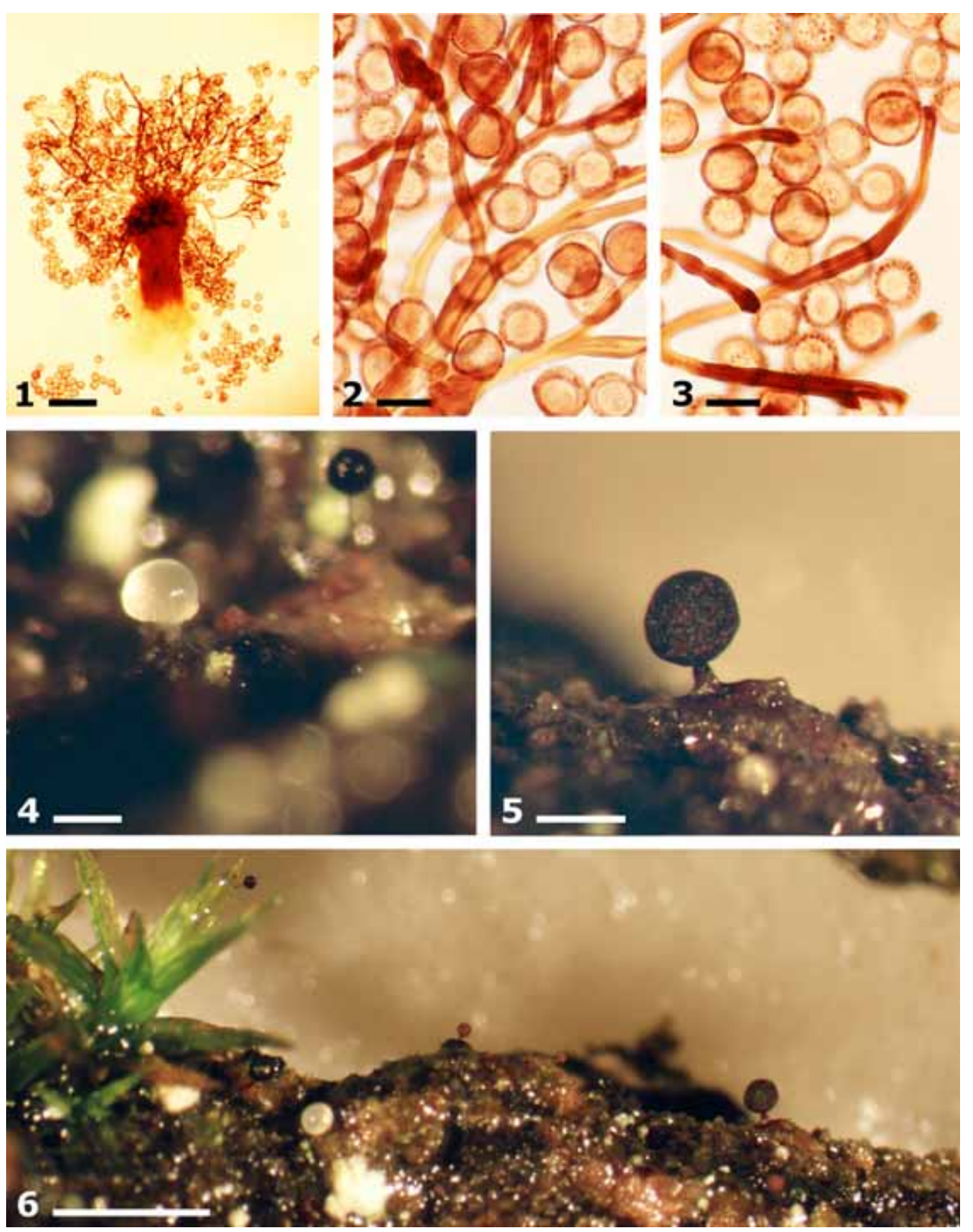

Figs. 1-6. Macbrideola sp. (Eliasson 6578). - 1: Slide preparation of whole fruitbody showing translucent stalk base and rounded columella. Bar: $50 \mu \mathrm{m} .-2$, 3: Capillitium and spores. Bar: $10 \mu \mathrm{m}$. - 4: Immature fruitbody. Bar: $0.2 \mathrm{~mm}$. - 5: Mature sporocarp. Bar: $0.2 \mathrm{~mm}$. -6 : Moist chamber culture with immature (left) and mature (right) fruitbodies. The small fruitbodies in the background are Macbrideola cornea. Bar: ca $1 \mathrm{~mm}$. 
Physarum crateriforme Petch

Västergötland: Töllsjö, mc, Oct 2005 Eliasson 6429, 6436, Mar 2007 Eliasson 6662, Oct 2008 Eliasson 7021, 7024.

All specimens are moist chamber cultures on bark from living Acer platanoides and are from the same locality. The specimens cited are very different from typically developed sporocarps of $P$. crateriforme and would be difficult to key out using standard identification literature.

Sporocarps are sessile or almost so, when dry $0.3-0.7 \mathrm{~mm}$ in diam. Columella is lacking and the degree of calcification highly variable. The capillitium varies from physaroid with just a few large nodes to badhamioid, in some sporothecae forming almost simple straight columns attached to the peridium in a way reminiscent of Badhamiopsis. Spores are mostly 10-12 $\mu \mathrm{m}$, globose to somewhat ovoid, characteristically pale by transmitted light with evenly spaced distinct warts or short spines. In young moist sporothecae, at least when calcium is scarce or lacking, the spore mass shines through the translucent peridium and the outer peridial surface may have small invaginations corresponding to where capillitial spines are attached on the inside, a feature reminiscent of Badhamiopsis. There is a wide range of variation in the Swedish material in the degree of calcification and the structure of the capillitium. Although sporocarps are predominantly sessile, a tendency to a short black stalk may be seen in some sporocarps.

The great variability of this species and the wide range of deviant fructifications often developed in moist chamber cultures on bark have been commented on by several authors (Lister 1925, Eliasson et al. 1988, Keller 1999). Typically the species has calcified sporothecae on a robust black stalk as long as or longer than the sporotheca, and a cylindrical columella, as apparent from material studied from other parts of the world, for example several states on the American mainland, the Hawaiian Islands and the Galápagos Islands. The spores are distinctive throughout all material studied of this species.

Due to the great variation exhibited by P. crateriforme caution should be taken when describing new species with one or several characters, in particular spore structure, in common with that species. Unless accompanied by typically developed fruitbodies sessile acolumellate sporocarps with scanty or no calcium may be difficult to identify. Many specimens left unidentified in herbaria may well represent forms of $P$. crateriforme. Mitchell's (2003) reduction of $P$. columellatum Nann.-Bremek. \& Y. Yamam. to a variety of $P$. crateriforme seems well justified.

Although the thinly scattered sporocarps are inconspicuous and easy to overlook especially when scanty in calcium the species does not seem to be very common in Europe. It has not previously been reported from Sweden.

Physarum diderma Rostaf.

Halland: Tjolöholm, extensive fruiting on large decaying $\log$ of Quercus, Oct 2001 Eliasson 5805 .

This is the third Swedish record of this apparently rare species. The two previous collections are from Stockholm and were made in Oct 1882 and Nov 1891 (Harling 1952). Interestingly, they were taken at the same time of year and in the same type of habitat (parkland with broadleaf trees) as the collection cited above.

\section{Physarum rubiginosum Fr.}

Lappland: Ca $4 \mathrm{~km}$ from Jokkmokk, just $\mathrm{N}$ of the Arctic Circle, Aug 2007 Eliasson \& Adamonyte 6825. Norrbotten: Vicinity of Sikfors, Aug 2007 Eliasson \& Adamonyte 6771; ca 3 km S of Älvsbyn, Aug 2007 Eliasson \& Adamonyte 6934. Halland: Falkenberg, Askome, Aug 1991 Marstad 28C-91.

Previously reported from the provinces of Småland, Östergötland, Uppland and Dalarna (Santesson 1964). Apparently a widespread species although seldom collected.

\section{Stemonitis pallida Wingate}

Halland: $15-20 \mathrm{~km}$ E of Falkenberg, mc, Jul 2003 Eliasson \& Gilert 6141. Västergötland: Askim, Jun 1995 Eliasson 4807.

Not previously reported from Sweden but probably an overlooked species.

Stemonitopsis amoena (Nann.-Bremek.) Nann.Bremek.(Comatricha amoena Nann.-Bremek.)Fig. 10.

Västergötland: Mölndal, Jul 1996 Eliasson 4973. Töllsjö, Aug 1970 Eliasson 2649, Aug 1997 Eliasson 5198, Jul 1998 Eliasson 5334, Aug. 1998 Eliasson 5339, Aug 2001 Eliasson 5718, 5721. All specimens cited are from decaying wood of Pinus and Populus. 

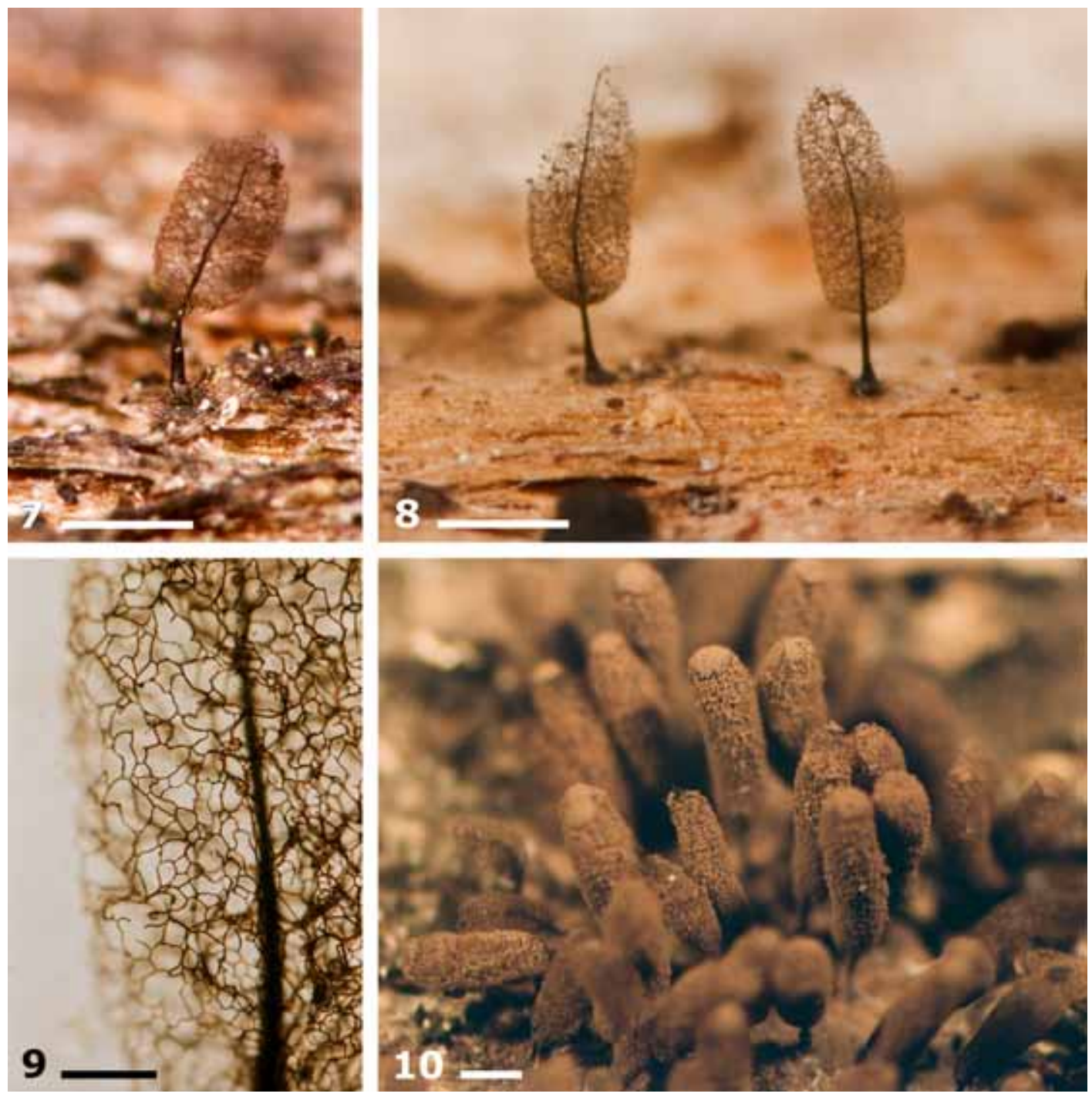

Figs. 7-9. Stemonitopsis subcaespitosa. - 7, 8: Mature fruitbodies with spores shed (7, Eliasson \& Adamonyte 6901; 8, Eliasson 5158). Bars: 0.2 mm. - 9: Portion of capillitium showing peripheral net (Eliasson \& Adamonyte 6901). Bar: $0.1 \mathrm{~mm}$. - Fig. 10: Stemonitopsis amoena (Eliasson 2649). Bar: ca. $0.5 \mathrm{~mm}$.

Although the ranges of spore size overlap somewhat in S. amoena and S. hyperopta (Meyl.) Nann.-Bremek., spores of the first species are generally slightly larger and darker in mass as well as seen by transmitted light. Spores of $S$. hyperopta may be almost colourless by transmitted light. The reticulate spore ornamentation in $S$. hyperopta is made up of faint bands, whereas bands are intermixed with warts or short spines in
S. amoena and the number of meshes is higher. The species is new to Sweden.

Stemonitopsis gracilis (G. Lister) Nann.-Bremek. (Comatricha pulchella var. gracilis G. Lister)

Norrbotten: Ca $5 \mathrm{~km} \mathrm{~S}$ of Sikfors, field collection, Aug. 2007 Eliasson \& Adamonyte 6860; a group of sporocarps developed in close association with sporocarps of Physarum notabile T. 
Macbr. on a small Pinus twig in the litter layer of open Pinus forest on rocky Cladina-covered ground.

Total height of sporocarps 1-1.2 mm; spores ca $7 \mu \mathrm{m}$, warted, wall thinner on one side; capillitial surface net incomplete.

The species is new to Sweden.

Stemonitopsis subcaespitosa (Peck) Nann.Bremek. (Comatricha subcaespitosa Peck) - Figs. 7-9

Västergötland: Töllsjö, Jul 1971 Eliasson 2856, 2863, Jul 1997 Eliasson 5158, 5180. Norrbotten: Ca $5 \mathrm{~km}$ from Älvsbyn along road to Piteå, Aug. 2007 Eliasson \& Adamonyte 6898, 6901; on ground-facing side of decorticated decaying branch of Pinus on rocky Cladina-covered ground in open Pinus forest.

Sporocarps ca $1 \mathrm{~mm}$ tall; spores 9.5-10.5 $\mu \mathrm{m}$, faintly but distinctly warted and tending to being paler on one side.

The species is new to Sweden.

Symphytocarpus impexus Ing \& Nann.-Bremek.

Västergötland: Göteborg, Västra Frölunda, May 2007 Eliasson 6689. Värmland: Övre Ullerud, July 1996 Lundqvist 20458 (S).

The species has not previously been formally reported from Sweden.

Acknowledgements: We are grateful to Mr. David Mitchell whose comments improved the manuscript and to Anna Lind for professional help with the illustrations.

\section{References}

Eliasson, U. H. \& Gilert, E. 2007: Additions to the Swedish myxomycete biota. - Karstenia 47: 29-36.

Eliasson, U. H., Keller, H. W. \& Hutchison, J. A. 1988: Myxomycetes from Arkansas. - Mycotaxon 32: 375398.

Fries, E. M. 1849: Summa Vegetabilium Scandinaviae. Sect. Post. Stockholm, Uppsala, Leipzig.

Fries, R. E. 1912: Den svenska myxomycetfloran. - Sv. Bot. Tidskr. 6: 721-802.

Harling, G. 1952: Notes on Myxomycetes. I. Physarum diderma Rost., new to Sweden. - Sv. Bot. Tidskr. 46: 47-52.

Ing, B. 1999: The Myxomycetes of Britain and Ireland. The Richmond Publishing Co. Ltd.

Keller, H. W. 1999: Myxomycetes of Ohio: their systematics, biology, and use in teaching. - Bull. Ohio Biol. Survey, New Ser. 13(2). Columbus, Ohio.

Kylin, H. 1998: Några intressanta svenska fynd av slemsvampar (myxomyceter). - Jordstjärnan 19: 19-20.

Lado, C. 2001: Nomenmyx, a nomenclatural taxabase of myxomycetes. - Cuad. Trab. Flora Micol. Ibér. 16.

Lister, A. 1925: A monograph of the Mycetozoa. Ed. 3 (revised by G. Lister). - British Museum of Natural History, London.

Marstad, P. 1995: Contribution to the corticolous myxomycetes in the Nordic countries. - Agarica 13(22): 39-48.

Mitchell, D. W. 2003: Physarum crateriforme var. columellatum. In McHugh, R., Stephenson, S. L., Mitchell, D. W. \& Brims, M. H., New records of Australian Myxomycota. - New Zeal. Journ. Bot. 41: 487-500.

Santesson, R. 1964: Swedish myxomycetes. - Sv. Bot. Tidskr. 58: 113-124.

Schinner, F. 1983: Myxomyceten aus dem Gebiet des Torne Träsk (Abisko) in Schwedisch Lappland. Sydowia, Ann. Mycol. 36: 269-276. 